\title{
Hepatitis B surface gene variants isolated from blood donors with overt and occult HBV infection in north eastern Egypt
}

Rania Kishk', Nader Nemr², Abeer Elkady ${ }^{3,4}$, Mohamed Mandour ${ }^{1,2}$, Mohamed Aboelmagd ${ }^{2}$, Nevene Ramsis ${ }^{5}$, Mohamed Hassan ${ }^{2}$, Nashaat Soliman ${ }^{2}$, Sayuki lijima ${ }^{4}$, Shuko Murakami ${ }^{4}$, Yasuhito Tanaka ${ }^{4^{*}}$ and Mostafa Ragheb ${ }^{6}$

\begin{abstract}
Background: Major hydrophilic region in genomic HBV extending from aa99 to aa169, clustered with a highly conformational epitope, is critical to the antigenicity of hepatitis B surface antigen ( $\mathrm{HBsAg}$ ) and may affect the diagnosis of HBV in HBV screening test. So, this study aimed to characterize variants of $\mathrm{S}$ gene product of hepatitis $B$ virus (HBV) isolated from patients with overt or occult HBV infection in north-eastern Egypt.

Methods: The study included sera of two different groups of volunteer blood donors (VBDs), 82 with overt HBV that were positive for $\mathrm{HBsAg}$ and anti-HBc and 343 donors negative for $\mathrm{HBsAg}$ eligible for donation. Of the latter group, only 44 were positive for anti-HBc. All anti-HBc positive sera were subjected to HBV DNA detection and partial sequence analysis targeting the HBV $\mathrm{S}$ gene.

Results: HBV DNA was detected in $22.7 \%$ of $\mathrm{HBsAg}$-/anti-HBC + (10/44 patients) and in $90 \%$ of HBsAg + donors (74/82 patients) with significant statistical difference $(P=0.0001)$. Phylogenetic analysis showed that HBV strains retrieved from both groups were of genotype D. Amino acid escape mutation T125M was detected in only 2 samples of the occult infection group and in none of the overt group $(P=0.01)$. Different amino acid substitutions were identified in overt infection group: S143L/T $(16.2 \%, 12 / 74)$ and P120T/S (2.7 \%, 2/74). Q129R was significantly more frequent in cases with occult HBV infection ( $40 \%, 4 / 10)$ than overt group $(6.8 \%, 5 / 74)(P=0.01)$.
\end{abstract}

Conclusions: HBV genotype D predominated both in patients with overt and occult HBV infection. Different profiles of amino acid substitutions in the major hydrophilic region were seen in these two groups in Egypt.

Keywords: Occult HBV, Genotype D, Escape mutation

\section{Background}

Hepatitis B virus (HBV) chronically infected 240 million people and leads to hepatitis, liver cirrhosis, and hepatocellular carcinoma. It is considered a major health problem in the world, especially in Asia, the Middle East, and Africa [1].

Hepatitis B surface antigen ( $\mathrm{HBsAg}$ ) is an envelope glycoprotein that serves as a primary target for diagnosis and immunoprophylaxis of HBV infection. The dominant epitopes of HBsAg, which are the targets of neutralizing antibody responses, reside in the "a" determinant

\footnotetext{
*Correspondence: ytanaka@med.nagoya-cu.ac.jp

${ }^{4}$ Department of Virology and Liver Unit, Nagoya City University Graduate School of Medical Science, Nagoya 467-8601, Japan

Full list of author information is available at the end of the article
}

(aa 124-147) within the major hydrophilic region (MHR). Amino acid substitutions in the MHR can cause reduced binding of anti-HBs antibodies, resulting in immune escape [2]. The major hydrophilic region, extending from aa99 to aa169, clustered with a highly conformational epitope, is critical to the antigenicity of HBsAg. Thus, amino acid substitution in the MHR, either from variants in natural isolates or mutants selected under immunological pressure, could cause incorrect diagnoses of HBV in the HBsAg screening test [3].

In Egypt, blood donation depends mainly on unpaid voluntary donors that could be either replacement or regular donors. Although, replacement donors could be either relatives or neighbors of blood recipients, the donated blood is used to replenish the stores of the blood 
bank rather to be given to a particular recipient except when rare blood groups are needed on emergency settings. Furthermore, selection of blood donors depends upon a screening system that excludes the subjects positive for HBsAg, anti-HCV, anti-HIV and anti-treponema antibody. Despite the importance of anti-HBc screening for safer blood transfusion [2, 3], this serological marker is not included in Egyptian blood bank screening. Then, such screening system in Egypt would miss occult HBV infection (OBI) among blood donors [2, 3].

Occult HBV infection (OBI) is defined as the longterm persistence of HBV DNA, despite undetectable HBsAg by regular immunoassays $[4,5]$. Evidence from different geographical regions documents that OBI is globally distributed and potentially a major source of HBV transmission through blood transfusion and organ transplantation [6, 7]. In the Middle East, an estimated $2-5 \%$ of the general population is chronically infected. Over the last two decades, , the endemicity of hepatitis $B$ infection has been changed from high to intermediate and low endemicity the prevalence of hepatitis B is lower (2-6\%) [8-10].

HBV vaccination was introduced in Egypt in 1992 as part of an expanded program of immunization for the newborn, in addition to its availability for populations at high risk (Mansour et al., 1993) [11]. The incidence of OBI in Egypt was assessed by Attia [1998] [12]. In north eastern Egypt where the current study was conducted, Youssef and colleagues reported OBI in $35(16.3 \%)$ of 214 hospitalized patients with elevated ALT levels, while only 10 (4.7\%) were positive for HBsAg [13].

This study aimed to characterize HBs antigen MHR variants in cases with overt and occult $\mathrm{HBV}$ infection in volunteer blood donors (VBDs).

\section{Results}

\section{General characteristics of the studied cohorts}

The study included 126 volunteer blood donors, consisting of 44 HBsAg-negative/anti-HBc-positive men and 82 HBsAg-positive subjects ( 74 men and 8 women) (median viral load was $\left.157.5660 \times 10^{3} \mathrm{IU} / \mathrm{m}\right)$. Both groups were matched regarding age and ALT level (Table 1). Female gender was significantly more frequent in donors with overt HBV infection compared to HBV-resolved group $(P=0.049)$. A significantly higher frequency of detectable HBV DNA by nested PCR was observed in cases with overt HBV infection $(74 / 82,90 \%)$ than in cases with occult HBV infection $(10 / 44,22.7 \%)(P=0.0001)$. Sequencing and phylogenetic analysis revealed that HBV sequences were of genotype $\mathrm{D}$ (data not shown).

\section{Genetic variants of $\mathrm{HBsAg}$ in the MHR}

In this study, MHR variants were found in $27 / 74$ $(37.8 \%)$ of cases with overt HBV infection and 3 in 5/10
(50\%) of cases with occult HBV. Five types of variants were observed in donors with overt HBV infection. The most prevalent variant was $\mathrm{S} 143 \mathrm{~L} / \mathrm{T}$ detected in 12 (16.2\%) of sequences, followed by T115S in 7 (9.5\%), Q129R in 5 (5.8 \%), P120T/S in 2 (2.7\%), and K141R in one (1.4\%) (Fig. 1a) (Table 1). In 10 cases with occult HBV infection, a different profile of amino acid substitutions was observed. The most frequent one was Q129R in 4 (40 \%) of the retrieved sequences, followed by $\mathrm{T} 125 \mathrm{M}$ in $2(20 \%)$ and $\mathrm{P} 127 \mathrm{~T}$ in one $(10 \%)$ sample (Fig. 1b) (Table 1). The well-known G145A/R variant was not observed in either the overt infection or occult infection group. T125M and Q129R amino acid substitutions were significantly more frequent in cases with occult HBV infection than in overt HBV infection (2 and 4 of 10 vs. 0 and 5 of $74, P=0.01$ for each) (Table 1 ). The most prevalent variant was $\mathrm{S} 143 \mathrm{~L} / \mathrm{T}$ detected in $16.2 \%$ of sequences, followed by T115S in $9.5 \%$, Q129R in $5.8 \%, \mathrm{P} 120 \mathrm{~T} / \mathrm{S}$ in $2.7 \%$, and K141R in $1.4 \%$ (Fig. 1a) (Table 1).

Among overt HBV group (82 patients), 47 patients (57.3\%) had mild viremia (36 wild type/11 mutant type), 17 patients $(20.7 \%)$ had moderate viremia (9 wild type/ 8 mutant type), 3 patients ( $3.7 \%$ ) had high viremia ( 2 wild type/1 mutant type), and 12 patients (14.6\%) had very high viremia (7 wild type/5 mutant type). The remaining 8 samples that were negative by real time PCR and positive HBsAg were assumed to contain HBV DNA below the detection limit of the assay.

In cases with occult HBV infection, a different profile of amino acid substitutions was observed. The most frequent one was Q129R in $40 \%(4 / 10)$ of the retrieved sequences, followed by $\mathrm{T} 125 \mathrm{M}$ in $20 \%$ and P127T in one sample (Fig. 1b) (Table 1). The well-known G145A/R variant was not observed in either the overt infection or occult infection group. T125M and Q129R amino acid substitutions were significantly more frequent in cases with occult HBV infection than in overt HBV infection $(P=0.01$ for each) (Table 1$)$.

\section{Criteria of blood donors with "HBsAg-/anti-HBC+"serological profile}

According to positivity for anti-HBs, blood donors with serological profile [(HBsAg-/anti-HBc+ $)]$ were sub-classified into two groups; 17 cases positive for both anti-HBc and anti-HBs [(anti-HBc+/anti-HBs+)] and 27 positive for only anti-HBc [anti-HBc+/anti-HBs-)]. HBV DNA was detected in 10 samples, 5 in each group with a prevalence of $29.4 \%$ in the [(anti-HBc+/anti-HBs+)] group, and $18.5 \%$ in the $[($ anti-HBc+/anti-HBs- $)]$ group. T125M was detected in one case in the anti-HBc+/antiHBs + group (sample ID, OCU 18) and in one case in the anti-HBc+/anti-HBs- group (sample ID, OCU 158) (Fig. 1b) (Table 2). However, Q129R was observed more 
Table 1 General characteristics of the studied cohort

\begin{tabular}{|c|c|c|c|c|}
\hline & $\begin{array}{l}\text { Total } \\
(n=126)\end{array}$ & $\begin{array}{l}\text { HBsAg-/anti-HBC+ } \\
(n=44)\end{array}$ & $\begin{array}{l}\text { HBsAg+ } \\
(n=82)\end{array}$ & $P$-value \\
\hline Age (Years) Mean \pm SD & $29.1 \pm 7.1$ & $32.9 \pm 6.1$ & $28.0 \pm 7$ & NS \\
\hline Gender (M) & $118(93.7)$ & $44(100 \%)$ & $74(90 \%)$ & 0.049 \\
\hline ALT (IU/L) & $18.8 \pm 10.6$ & $18.6 \pm 13.9$ & $19 \pm 7.2$ & NS \\
\hline HBV DNA S region (+) & $84(66.7 \%)$ & $10(22.7 \%)$ & $74(90 \%)$ & 0.0001 \\
\hline MHR Substitutions (\%) & $34 / 84(40.5)$ & $7 / 10(50)^{a}$ & 27/74 (37.8) & 0.5 \\
\hline T115S & $7 / 84(8.3)$ & 0 & $7 / 74(9.5)$ & NS \\
\hline P120T/S & $2 / 84(2.3)$ & 0 & 2/74 (2.7) & NS \\
\hline $\mathrm{T} 125 \mathrm{M}$ & 2/84 (2.3) & $2 / 10(20)$ & 0 & 0.01 \\
\hline P127T & $1 / 84(1.2)$ & $1 / 10(10)$ & 0 & NS \\
\hline Q129R & 9/84 (10.7) & $4 / 10(40)$ & $5(5.8)$ & 0.01 \\
\hline $\mathrm{K} 141 \mathrm{R}$ & $1 / 84(1.2)$ & 0 & $1(1.4)$ & NS \\
\hline $\mathrm{S} 143 \mathrm{~L} / \mathrm{T}$ & $12 / 84(14.3)$ & 0 & $12(16.2)$ & NS \\
\hline
\end{tabular}

${ }^{\mathrm{a}}$ Two MHR mutants were present simultaneously in 2 cases; OCU18 and OCU158

frequently in anti-HBc+/anti-HBs + group $(3 / 5,60 \%)$ than in anti-HBc+/anti-HBs- group (1/5, $20 \%)$, but this difference did not reach statistical significance.

\section{Descriptive analysis of cases with occult HBV infection}

HBV DNA was detected in 10 of 44 HBsAg-negative/ anti-HBc-positive blood donors (22.7 \%). The mean age of cases with occult HBV infection was $32.9+6.1$ years, all men (Table 3). All had normal ALT values (range; 9$22 \mathrm{U} / \mathrm{L}$ ). Interestingly, 5 cases were serologically positive for anti-HBs. However, only two samples had an antiHBs level $>100 \mathrm{IU} / \mathrm{L}(1000 \mathrm{IU} / \mathrm{L}$ and $147 \mathrm{IU} / \mathrm{L}$ in samples ID OCU 18 and OCU 43, respectively), while low levels of anti-HBs were detected in the remaining 3 samples $(23.5,12.4,12.2 \mathrm{IU} / \mathrm{L}$ in OCU234, OCU340 and OCU243, respectively) (Table 3). T125M and Q129R substitutions were simultaneously present in only one subject positive for anti-HBs (OCU 18) (Table 3, Fig. 1b). The T125M HBsAg variant in the MHR was detected in one sample negative for anti-HBs (OCU158), while Q129R alone was detected in a further 3 samples. One of the latter was negative for anti-HBs (OCU 309) and the remaining two were positive (OCU340, 243) (Table 3, Fig. 1b). With the exception of one case all samples showed low HBV DNA level [(OCU 274), HBV DNA = $4.7 \log (\mathrm{copy} / \mathrm{ml})]$. The viral load for the remained cases with occult HBV infection varied between 2.2-2.8 log copy $/ \mathrm{ml}$ and 3 cases were below the detection limit of the assay. .Interestingly, the sample with the highest viral load in the occult HBV infection group exhibits no amino acid substitution in the MHR genomic region (OCU274).

\section{Discussion}

In this study, Occult HBV infection was detected in $22.7 \%$ of blood donors negative for HBsAg but positive for anti-HBc, indicating that at least a quarter of cases positive for the latter had detectable HBV DNA and thus the likelihood of transmission of HBV through their blood products [14]. Said et al. (2013) reported an incidence of $17.2 \%$ among a cohort similar to that of the current study [3]. Different risk factors are reported to be associated with OBI including age, male gender, antiHBs level $<100 \mathrm{mIU} / \mathrm{L}$ and positivity for anti-HBc in Egypt [3].

In Egypt, $\mathrm{HBV}$ screening in blood banks relies only on the detection of HBsAg. Screening for HBV by the nucleic acid amplification test (NAT) is effective in reducing the transmission of HBV via blood and blood products. In developing countries like Egypt, the high cost of the NAT may prevent its application as an essential strategy for blood-borne virus screening. Anti-HBc has been found to be an excellent indicator of the occult HBV infection and the detection of the anti-HBc [14-16] has contributed significantly in reducing the incidence of post transfusion hepatitis B $[17,18]$. In this regard, measurement of anti$\mathrm{HBC}$ would be more practical and may be considered as a second safeguard policy for reducing the transmission of HBV via blood products [2]. Despite the importance of anti-HBc screening for safer blood, this serological marker is not included in Egyptian blood bank screening. Then, such screening system in Egypt would miss OBI among blood donors [2-4].

The predominance of infection with HBV genotype D among cases with overt and occult HBV infection in Egypt, a previous finding supported by the present study, has allowed the analysis of $\mathrm{S}$ gene variants of HBV strains isolated from cases with occult and overt HBV infection who were resident in north eastern Egypt $[19,20]$. The selection of samples from volunteer blood donors gives a more representative spectrum of the immune-pathological 


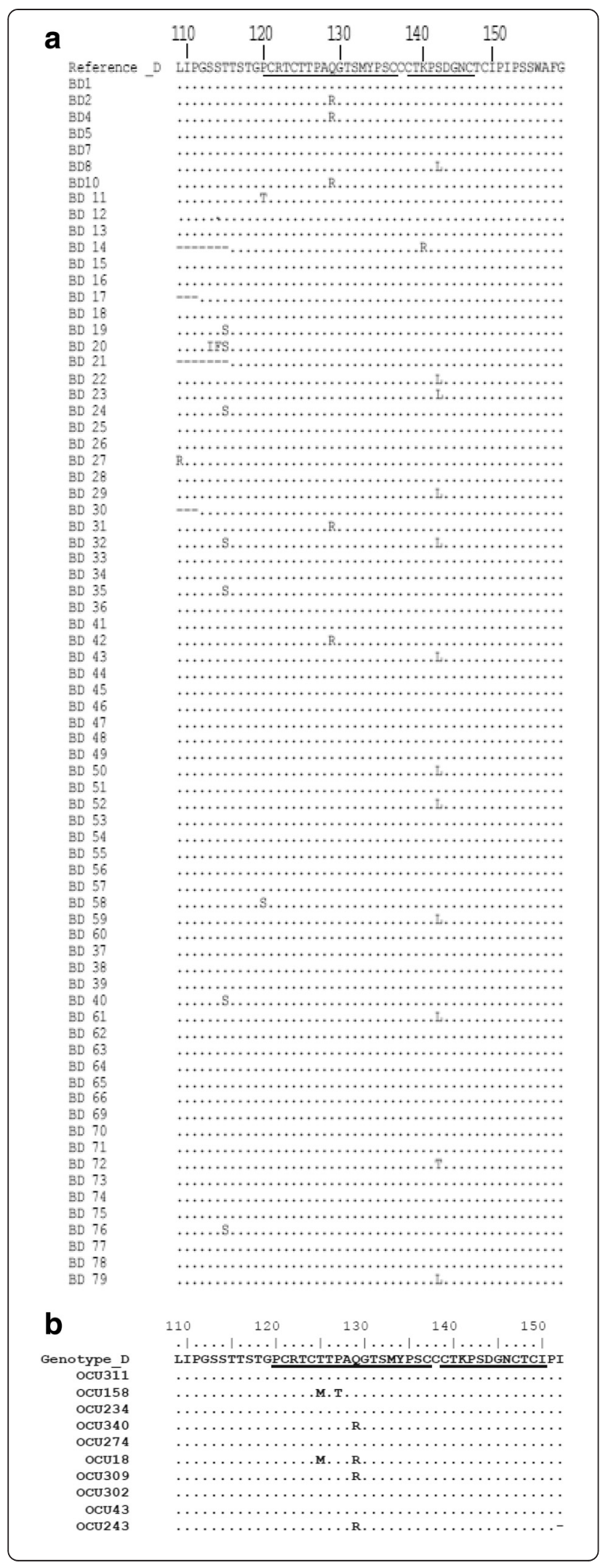

Fig. 1 Alignment of amino acid sequences of the HBV partial surface gene encompassing the "a" determinant region isolated from cases with overt HBV infection a and from cases with occult $\mathrm{HBV}$ infection $\mathbf{b}$. The detected sequences were aligned with respect to a consensus sequence of HBV genotype D retrieved from DDBJ/ GenBank database. Dots in alignment indicate identity with the consensus sequence of genotype D. First and second loop positions are underlined in the consensus sequence of the genotype

pattern of HBV infection in the general population than patients' samples that would bias the results toward a specific immune variant of the disease [21]. Understanding the prevalence and types of HBsAg variants is of high importance, because this will affect policy decisions relating to vaccine and diagnostic reagent design.

The proportion of samples positive for anti-HBc antibody among HBsAg-negative blood donors was $12.8 \%$. This is higher than that previously reported anti-HBc prevalence rates among HBsAg-negative blood donors in the Mediterranean region (2.1 in Iran) [22] and the $5.6 \%$ in Saudi Arabia [23].

Data regarding the amino acid changes of HBsAg in Egypt, particularly in the general population, are scarce. Variations in the alpha determinant region were observed in $37.8 \%$ of strains isolated from HBsAg-positive blood donors and in $50 \%$ of occult HBV. The incidence of HBsAg variants among random chronic carriers with HBV genotype D varied between $15 \%$ in Morocco and $17.2 \%$ in Iran [24]. However, Garmini et al. (2011) reported that the substitution rate in the MHR was $0.4 \%$ in HBV genotype D strains isolated from HBsAg-positive blood donors in Iran [21]. Different studies in China (where genotypes $\mathrm{C}$ and $\mathrm{B}$ are prevalent) documented that mutation rates within $\mathrm{HBsAg}$-positive blood donors ranged between $14.7 \%$ in Shandong province to $50 \%$ in Nanjing. This large difference was explained by the wider application of $\mathrm{HBV}$ vaccine in Nanjing [25].

Studying the underlying mechanisms of the occult HBV infection in certain poulationmay require; (1) large size studied population and (2) in vitro and in vivo experimental work to explore the virological characteristics of the detected substitutions. Despite the small number of cases with occult HBV obtained in the present study, all (with exception of one) exhibit a low viral load even in cases with MHR mutants. This finding may support the hypothesis that OBI cases are secondary to overt HBV infection and represent a residual low viremia level suppressed by strong immune response together with histological derangements occurring during acute or chronic HBV infection [22, 23].

Differences were observed between the two cohorts studied here in the type of predominant amino acid substitutions in the isolated MHR of HBsAg despite both groups originating from volunteer blood donors. 
Table 2 Characteristics of blood donors negative for HBsAg and positive for anti-HBc/anti-HBs

\begin{tabular}{|c|c|c|c|c|}
\hline & $\begin{array}{l}\text { Total } \\
(n=44)\end{array}$ & $\begin{array}{l}\text { Anti-HBC positive/ } \\
\text { anti-HBs positive } \\
(n=17)\end{array}$ & $\begin{array}{l}\text { Anti-HBC positive/ } \\
\text { anti-HBs negative } \\
(n=27)\end{array}$ & $P$-value \\
\hline Age (Mean \pm SD ) & $30 \pm 7.1$ & $32.3 \pm 6.7$ & $28.3 \pm 7.2$ & 0.055 \\
\hline $\operatorname{ALT}(U / L)$ & $20.5 \pm 15.9$ & $20.9 \pm 15.9$ & $20.2 \pm 16.2$ & NS \\
\hline HBV DNA S region (+) & $10(22.7 \%)$ & $5(29.4 \%)$ & $5(18.5 \%)$ & NS \\
\hline \multicolumn{5}{|l|}{ MHR substitutions } \\
\hline $\mathrm{T} 125 \mathrm{M}$ & $2 / 10(20 \%)$ & $1 / 5$ & $1 / 5$ & NS \\
\hline Q129R & $4 / 10(40 \%)$ & $3 / 5$ & $1 / 5$ & NS \\
\hline
\end{tabular}

Significant predominance of amino acid substitutions T125M and Q129R was observed in HBsAg isolated from occult hepatitis B cases. In the study by Candotti et al. (2008), T125M was detected in $11.9 \%$ of cases with occult HBV genotype D, while none of the patients with occult HBV genotype A harbored this mutant strain [26]. The T125M substitution represents a nonconservative amino acid change which may affect the conformation of the HBsAg a determinant region and thus the binding of HBsAg-specific antibody [27]. However, one in vitro study indicated that this substitution failed to influence the binding of HBsAg to monoclonal or polyclonal antibodies [28].

Recent in vitro studies found that Q129R significantly impaired virion and/or S protein secretion in $\mathrm{HuH7}$ cells and in mice is associated with lower reactivity in $\mathrm{HBsAg}$ assays [29]. While T125M and Q129R were the predominant HBsAg variants in these occult HBV cases, P120T and S143L were more frequent in $\mathrm{HBsAg}+$ blood donors. Interestingly, these substitutions were previously described in blood donors with occult HBV infection of genotype D [30].

In the present study, $29.4 \%$ of cases positive for both anti-HBc and anti-HBs possessed detectable levels of HBV-DNA. These results are in accordance with those of Brojer et al. (2006) [31] and Katsoulidou et al. (2009)
[32] who found that nearly $50 \%$ of OBI are asymptomatic, apparently healthy blood donors carriers of antiHBs [31, 32]. Similarly, Yotsuyanagi et al. (2001) found that low levels of HBV DNA was detected in the sera from 19 (38 \%) of $50 \mathrm{HBsAg-/anti-HBc}+$ donors. In 8 (16\%) of them, HBV did not exist as immune complexes. thus in a potentially infective form [33]. Part of this may be explained by the findings of Levicnik-Stezinar et al. (2008) who concluded that low levels of anti-HBs $<100 \mathrm{mIU} / \mathrm{L}$ have limited neutralizing capacity [34].

\section{Conclusion}

The profiles of the predominant amino acid substitutions different between cases with occult and overt HBV infection were detected in the alpha determinant region of the HBsAg (MHR) in blood samples from Egyptian donors. Further large population size studies are needed to explore the magnitude of occult $\mathrm{HBV}$ infection in Egypt and to detect HBsAg variants affecting reactivity in the HBsAg assays. The present study highlights the need for revising the strategy used for screening HBV in blood donors and blood products in Egypt. In the light of point the high cost of HBV DNA testing for all collected blood units, the present study recommends the inclusion of anti-HBc in the routine screening of blood donors in Egypt.

Table 3 Descriptive analysis of cases with occult HBV infection

\begin{tabular}{|c|c|c|c|c|c|c|c|}
\hline Sample ID & Age & $\mathrm{ALT}(\mathrm{IU} / \mathrm{L})$ & Anti-HBs & Anti-HBs level (mlU/L) & MHR amino acid substitutions & HBV DNA (core region) & HBV DNA Log (copy/ml) \\
\hline OCU234 & 38 & 22 & $(+)$ & 23.5 & - & $(+)$ & 2.8 \\
\hline OCU340 & 32 & 16 & $(+)$ & 12.4 & Q129R & $(+)$ & 2.7 \\
\hline OCU18 & 28 & 12 & $(+)$ & 1000.0 & T125M, Q129R & $(-)$ & $<2.0$ \\
\hline OCU43 & 31 & 23 & $(+)$ & 147.2 & - & $(+)$ & 2.3 \\
\hline OCU243 & 38 & 9 & $(+)$ & 12.2 & Q129R & $(+)$ & 2.8 \\
\hline OCU309 & 45 & 17 & $(-)$ & 0.1 & Q129R & $(-)$ & $<2.0$ \\
\hline OCU302 & 33 & 17 & $(-)$ & 0.8 & - & $(+)$ & 2.5 \\
\hline OCU274 & 32 & 12 & $(-)$ & 9.3 & - & $(+)$ & 4.5 \\
\hline OCU158 & 24 & 17 & $(-)$ & 0.1 & $\mathrm{~T} 125 \mathrm{M}$ & $(+)$ & $<2.0$ \\
\hline OCU311 & 28 & 12 & $(-)$ & 2.9 & - & $(-)$ & 2.2 \\
\hline
\end{tabular}




\section{Study design \\ Donors}

The studied subjects in this work included two different groups of blood donors; the first group included 82 individuals who were positive for $\mathrm{HBsAg}$ and rejected for donation. The second group included 343 donors who were accepted for donation; being negative $\mathrm{HBsAg}$, anti$\mathrm{HCV}$, anti-HIV and anti-treponema antibody. All blood donors were randomly selected from blood bank. Serum samples from the 343 HBsAg-negative donors were tested for antibodies to hepatitis B core antigen (anti$\mathrm{HBc}$ ). Forty four (12.8\%) of $343 \mathrm{HBsAg-negative} \mathrm{blood}$ donors were positive for anti-HBc. The latter group was further serologically tested for HBsAg antibody (anti$\mathrm{HBs}$ ). Finally the study included two groups of sera: one positive for anti-HBc and negative for HBsAg $(n=44)$, and the second group of HBsAg-positive sera $(n=82)$.

\section{Serological Markers of HBV Infection}

HBsAg was determined by ELISA (Diasorin, Italy) and further confirmed by chemiluminescence enzyme immunoassay (CLEIA) (Fujirebio, Tokyo,Japan) with a detection limit of $0.05 \mathrm{IU} / \mathrm{ml}$. Anti-HBc and anti-HBs were tested by enzyme immunoassay (EIA) (AxSYM; Abbott Japan, Tokyo, Japan). All serologic assays were carried out according to the manufacturer's instructions.

\section{DNA Extraction}

The HBV/DNA was extracted from $200 \mu \mathrm{l}$ of serum samples positive for HBsAg using the QIAamp DNA MiniKit (QIAGEN, Inc., Hilden, Germany), and resuspended in $100 \mu \mathrm{l}$ of a storage buffer provided by the kit manufacturer.

\section{HBV DNA Quantification}

HBV-DNA was quantified by real-time detection polymerase chain reaction (RTD-PCR) primers according to the previously described protocol. The method was applied with slight modification as described previously $[14,15]$. The detection limit was 100 copies/ml. The extracted samples were tested for the presence of $\mathrm{HBV}$ DNA by 7500 Real time PCR machine to determine the viral load by using the following primers \& probe set:

\section{PF: 5'-CTTCATCCTGCTGCTATGCCT-3', PR: 5' AAAGCCCAGGATGATGGGAT-3' Probe: SP2: FAM-ATGTTGCCCGTTTGTCCTCT AATTCCAG-TAMRA)}

The $25 \mu \mathrm{l}$ reaction mixture volume contained $0.5 \mu \mathrm{l}$ of each primer (10 pico mol/ul) and the probe (SB2), $6 \mu \mathrm{l}$ water (PCR-grade), $5 \mu \mathrm{l}$ of DNA template and $12.5 \mu \mathrm{l}$ of the Taq polymerase. Cycling conditions were $10 \mathrm{~min}$ at $95{ }^{\circ} \mathrm{C}, 95^{\circ} \mathrm{C}$ for $15 \mathrm{sec}$, and $60{ }^{\circ} \mathrm{C}$ for 1 min for 45 cycles.
Fluorescence acquisition was taken once per cycle using FAM as a reporter dye and TAMARA as a quencher dye. The detection limit was 100 copies $/ \mathrm{ml}$.

\section{HBV genome amplification and sequencing}

The $\mathrm{S}$ gene of the HBV genome (681 bp) was amplified by hemi nested PCR using specific primers. The method was applied with slight modification as described previously $[14,35]$. For the first PCR (nucleotide positions 18-989):

- forward primer (IS1):5'-AAGCTCTGCTAGA TCCCAGAGT-3'

- Reverse primer (HS4R): 5'- CATACTTTCCAA TCAATAGG-3'

For the second PCR (nucleotide positions 414-989):

- Forward primer (SB1): 5'- TGCTGCTATGC CTCATCTTC-3'

- Reverse primer (HS4R): 5'- CATACTTTCCAA TCAATAGG-3'

Cycling conditions were $7 \mathrm{~min}$ at $96{ }^{\circ} \mathrm{C}, 96^{\circ} \mathrm{C}$ for $45 \mathrm{sec}$, and $55^{\circ} \mathrm{C}$ for $45 \mathrm{sec}$ and $72{ }^{\circ} \mathrm{C}$ for $45 \mathrm{sec}$ for 45 cycles.

For undetectable PCR products by the previous PCR protocol, we performed hemi-nested PCR with AmpliTaq Gold ${ }^{\odot}$ DNA Polymerase (Applied Biosystems, Waltham, MA, US). The amplicons of the genomic HBV enclosed the a determinant region of the $\mathrm{S}$ gene was obtained by hemi-nested PCR with forward primer HBSF2 : (5'-CTTCATCCTGCTGCTATGCCT-3' [nt 406-426]) and reverse primer HBSR2: (5'-AAAGCCCAGGATGAT GGGAT-3' [nt 608-627]) for the first PCR and forward primer HBSF2 : (5'-CTTCATCCTGCTGCTATGCCT-3' [nt 406-426]) and reverse primer HBSR3. The PCR reaction was undertaken for 60 cycles $\left(96{ }^{\circ} \mathrm{C}\right.$ for $15 \mathrm{sec}$., $60{ }^{\circ} \mathrm{C}$ for $1 \mathrm{~min}$.) followed by an extension reaction at $72{ }^{\circ} \mathrm{C}$ for $7 \mathrm{~min}$.

The enhancerII/core promoter and precore regions of the HBV genome were amplified by PCR with a forward primer (IS2-2: 5'-CAT GGAGAC CAC CGT GAA CGC-3' [nt 1607-1627]) and reverse primer (HBV1917R: 5' -CTC CAC AGA AGC TCC AAA TTCTTT A-3' [nt 1942-1918]). PCR was initiated by the hot-star technique. The PCR reaction was undertaken for 60 cycles $\left(96^{\circ} \mathrm{C}\right.$ for $15 \mathrm{sec}$., $60^{\circ} \mathrm{C}$ for $1 \mathrm{~min}$.) followed by an extension reaction at $72{ }^{\circ} \mathrm{C}$ for $7 \mathrm{~min}$.

Sequencing and Molecular Evolutionary Analysis of HBV Amplicons were sequenced directly using the ABI Prism Big Dye ver. 3.1 kit in the ABI 3100 DNA automated sequencer (Applied Biosystems, Foster City, CA, USA). All sequences were analyzed in both forward and reverse directions with same primers used for $\mathrm{HBV}$ genomic 
amplification. HBV genotypes were determined by sequence and molecular evolutionary analysis. Reference HBV sequences were retrieved from the DDBJ/EMBL/ GenBank database, aligned by CLUSTALX, and genetic distances estimated with the 6-parameter method in the Hepatitis Virus Database (http://s2as02.genes.nig.ac.jp/) [16]. Based on obtained distances, phylogenetic trees were constructed by the neighbor-joining (NJ) method with the mid-point rooting option. To confirm the reliability of the phylogenetic trees, bootstrap resampling tests were performed 1000 times for analysis by the ODEN program of the National Institute of Genetics. The deduced amino acid sequences of the HBsAg a-determinant regions in the donor HBV strains were compared to the HBV genotype D reference strains as proposed previously [17]; and to the amino acid sequences as present in the public domain databases, using the protein-protein Blast utility [18]. The nucleotide sequences data described in this paper will appear in the DDBJ/EMBL/GenBank sequences database with accession numbers; AB981241-AB981313 and AB981171-AB981180.

\section{Statistical analysis}

Statistical analysis was performed with the Fisher's exact probability test and the independent t-test for the continuous variables using the SPSS software package (SPSS, Chicago, IL, USA). $P$-values (two-tailed) less than 0.05 were considered to be statistically significant.

\section{Ethical consideration}

This study was approved by research ethics committee, Faculty of Medicine, Suez Canal University (No. 973)

\section{Ethics, consent and permissions}

Informed written consent was taken from the patients under study. The confidentiality of any information pertaining to the patients was assured. No obligation on the patients to participate in the study.

\section{Consent to publish}

We have obtained written consent from all participants to publish their data.

\section{Competing interest}

The authors declare that they have no competing interest.

\footnotetext{
Authors' contributions

RK: molecular genetics study, participation in sequence alignment, participation in sample collection, writing final manuscript. NN: sampling, data collection, text revision and final manuscript approval. AE, molecular genetics study, sequence alignment, writing final manuscript. MM: study design, sampling, text revision and final manuscript approval. MA: sampling, revision of final manuscript. NR: study design, revision of final manuscript. $\mathrm{MH}$ : study design, revision of final manuscript. NS: study design, revision of final manuscript. SI: sequence alignment, revision of final manuscript. SM: participation in sequence alignment, final manuscript approval. YT: molecular genetics study, participation in sequence alignment, final manuscript approval. All authors read and approved the final manuscript.
}

\section{Funding}

This study was supported by The Grant for National Center for Global Health and Medicine (22A-9). This study was also supported in part by a grant-in-aid from the Ministry of Health, Labour and Welfare of Japan, and a grant-in-aid from the Ministry of Education, Culture, Sports, Science and Technology.

\section{Author details}

${ }^{1}$ Department of Microbiology and Immunology, Faculty of Medicine, Suez Canal University, El Salam District, Ismaïlia, Egypt. ${ }^{2}$ Department of Endemic and Infectious diseases, Faculty of Medicine, Suez Canal University, El Salam District, Ismaïlia, Egypt. ${ }^{3}$ Department of Clinical and Chemical Pathology, Faculty of Medicine, South Valley University, Qena, Egypt. ${ }^{4}$ Department of Virology and Liver Unit, Nagoya City University Graduate School of Medical Science, Nagoya 467-8601, Japan. ${ }^{5}$ Department of Clinical Pathology, Faculty of Medicine, Suez Canal University, El Salam District, Ismaïlia, Egypt.

${ }^{6}$ Department of Internal Medicine, College of Medicine, Aljouf University, Sakaka, KSA, Saudi Arabia.

Received: 30 March 2015 Accepted: 21 September 2015

Published online: 30 September 2015

\section{References}

1. WHO Fact sheet $\mathrm{N}^{\circ} 204$ (Updated March 2015) http://www.who.int/ mediacentre/factsheets/fs204/en/

2. El-Sherif AM, Abou-Shady MA, Al-Hiatmy MA, Al-Bahrawy AM, Motawea EA. Screening for hepatitis $B$ virus infection in Egyptian blood donors negative for hepatitis B surface antigen. Hepatol Int. 2007;1:469-70.

3. Said ZN, Sayed MH, Salama II, Aboel-Magd EK, Mahmoud MH, Setouhy ME, et al. Occult hepatitis B virus infection among Egyptian blood donors. World J Hepatol. 2013:5:64-73.

4. Said ZN. An overview of occult hepatitis B virus infection. World J Gastroenterol. 2011;17:1927-38.

5. Hu KQ. Occult hepatitis B virus infection and its clinical implications. J Viral Hepat. 2002;9:243-57.

6. Allain JP. Occult hepatitis B virus infection: implications in transfusion. Vox Sang. 2004;86:83-91.

7. Romero M, Madejon A, Fernandez-Rodriguez C, Garcia-Samaniego J. Clinical significance of occult hepatitis B virus infection. World J Gastroenterol. 2010;17:1549-52

8. Sherif MM, Abou-Aita BA, Abou-Elew MG, et al. Hepatitis B virus infection in upper and lower Egypt. J Med Virol. 1985;15(2):129-35.

9. Shalaby S, Kabbash IA, El Saleet G, et al. Hepatitis B and C viral infection: prevalence, knowledge, attitude and practice among barbers and clients in Gharbia governorate. Egypt East Mediterr Health J. 2010;16(1):10-7.

10. Ismail AM, Ziada HN, Sheashaa HA, et al. Decline of viral hepatitis prevalence among asymptomatic Egyptian blood donors: a glimmer of hope. Eur J Intern Med. 2009;20(5):490-3.

11. Mansour E, Abdul-Rahim S, Batouty G, Zaghloul I, Abdel-Hadi S. Integration of hepatitis B immunization in the Expanded Program on Immunization of the Child Survival Project. J Egypt Public Health Assoc. 1993;68(5-6):487-94.

12. Attia MA. Prevalence of hepatitis $B$ and $C$ in Egypt and Africa. AntivirTher. 1998:3 Suppl 3:1-9.

13. Youssef A, Yano Y, Utsumi T, Abd El-alah EM, Abd El-Hameed Ael E, Serwah Ael $\mathrm{H}$, et al. Molecular epidemiological study of hepatitis viruses in Ismailia, Egypt. Intervirology. 2009;52:123-31

14. Abe A, Inoue K, Tanaka T, Kato J, Kajiyama N, Kawaguchi R, et al. Quantitation of hepatitis B virus genomic DNA by real-time detection PCR. J Clin Microbiol. 1999:37:2899-903.

15. Tanaka Y, Hasegawa I, Kato T, Orito E, Hirashima N, Acharya SK, et al. A case-control study for differences among hepatitis B virus infections of genotypes A (subtypes Aa and Ae) and D. Hepatology. 2004;40:747-55.

16. Shin IT, Tanaka Y, Tateno Y, Mizokami M. Development and public release of a comprehensive hepatitis virus database. Hepatol Res. 2008;38:234-43.

17. Bartholomeusz A, Schaefer S. Hepatitis B virus genotypes: comparison of genotyping methods. Rev Med Virol. 2004;14:3-16.

18. Altschul SF, Madden TL, Schaffer AA, Zhang J, Zhang Z, Miller W, et al. Gapped BLAST and PSI-BLAST: a new generation of protein database search programs. Nucleic Acids Res. 1997;25:3389-402

19. Saudy N, Sugauchi F, Tanaka Y, Suzuki S, Aal AA, Zaid MA, et al. Genotypes and phylogenetic characterization of hepatitis $B$ and delta viruses in Egypt. J Med Virol. 2003;70:529-36. 
20. Ragheb M, Elkady A, Tanaka Y, Murakami S, Attia FM, Hassan AA, et al. Multiple intra-familial transmission patterns of hepatitis B virus genotype D in north-eastern Egypt. J Med Virol. 2012;84:587-95.

21. Garmiri P, Rezvan H, Abolghasemi $H$, Allain JP. Full genome characterization of hepatitis B virus strains from blood donors in Iran. J Med Virol. 2014;83:948-52.

22. Sofian M, Aghakhani A, Izadi N, Banifazl M, Kalantar E, Eslamifar A, et al. Lack of occult hepatitis B virus infection among blood donors with isolated hepatitis B core antibody living in anHBV low prevalence region of Iran. Int J Infect Dis. 2010;14(4):e308-10.

23. Mohammed Abdullah S. Prevalence of hepatitis B and C in donated blood from the jazan region of saudi arabia. Malays J Med Sci. 2011;20(2):41-6.

24. Mohebbi SR, Amini-Bavil-Olyaee S, Zali N, Noorinayer B, Derakhshan F, Chiani M, et al. Molecular epidemiology of hepatitis B virus in Iran. Clin Microbiol Infect. 2008;14:858-66.

25. Japhet MO, Adesina OA, Donbraye E, Adewumi MO. Hepatitis B core IgM antibody (anti-HBclgM) among hepatitis B surface antigen ( $\mathrm{HBsAg}$ ) negative blood donors in Nigeria. Virol J.2011;8:513.

26. Candotti D, Grabarczyk P, Ghiazza P, Roig R, Casamitjana N, ludicone P, et al. Characterization of occult hepatitis $B$ virus from blood donors carrying genotype A2 or genotype D strains. J Hepatol. 2008;49:537-47.

27. Araujo NM, Vianna CO, Moraes MT, Gomes SA. Expression of Hepatitis B virus surface antigen ( $\mathrm{HBs} A \mathrm{Ag})$ from genotypes $\mathrm{A}, \mathrm{D}$ and $\mathrm{F}$ and influence of amino acid variations related or not to genotypes on HBsAg detection. Braz J Infect Dis. 2009;13:266-71.

28. Zheng X, Weinberger KM, Gehrke R, Isogawa M, Hilken G, Kemper T, et al. Mutant hepatitis B virus surface antigens ( $\mathrm{HBsAg}$ ) are immunogenic but may have a changed specificity. Virology. 2004;329:454-64.

29. Huang CH, Yuan Q, Chen PJ, Zhang YL, Chen CR, Zheng QB, et al. Influence of mutations in hepatitis $B$ virus surface protein on viral antigenicity and phenotype in occult HBV strains from blood donors. J Hepatol. 2012;57:720-9.

30. Zaaijer HL, Torres P, Ontanon A, Ponte LG, Koppelman MH, Lelie PN, et al. Multiple surface antigen mutations in five blood donors with occult hepatitis B virus infection. J Med Virol. 2008;80:1344-9.

31. Brojer E, Grabarczyk P, Liszewski G, Mikulska M, Allain JP, Letowska M. Characterization of HBV DNA+/HBsAg- blood donors in Poland identified by triplex NAT. Hepatology. 2006:44:1666-74.

32. Katsoulidou A, Paraskevis D, Magiorkinis E, Moschidis Z, Haida C, Hatzitheodorou E, et al. Molecular characterization of occult hepatitis B cases in Greek blood donors. J Med Virol. 2009;81(5):815-25.

33. Yotsuyanagi $H$, Yasuda K, Moriya K, Shintani $Y$, Fujie $H$, Tsutsumi T, et al. Frequent presence of $\mathrm{HBV}$ in the sera of $\mathrm{HBsAg}$-negative, anti-HBc-positive blood donors. Transfusion. 2001;41:1093-9.

34. Levicnik-Stezinar S, Rahne-Potokar U, Candotti D, Lelie N, Allain JP. Anti-HBs positive occult hepatitis $B$ virus carrier blood infectious in two transfusion recipients. J Hepatol. 2008:48:1022-5.

35. Yuan J, Zhou B, Tanaka Y, Kurbanov F, Orito E, Gong Z, et al. Hepatitis B virus (HBV) genotypes/subgenotypes in China: mutations in core promoter and precore/core and their clinical implications. J Clin Virol. 2007;39:87-93.

\section{Submit your next manuscript to BioMed Central and take full advantage of:}

- Convenient online submission

- Thorough peer review

- No space constraints or color figure charges

- Immediate publication on acceptance

- Inclusion in PubMed, CAS, Scopus and Google Scholar

- Research which is freely available for redistribution 